\title{
ANALISIS DETERMINAN AKUNTABILITAS PENGELOLAAN KEUANGAN DAERAH (Studi empiris pada SKPD Pemerintah Kabupaten Kepulauan Talaud)
}

\author{
LESLI L. AIMBU ${ }^{1)}$ DAVID P.E. SAERANG ${ }^{2)}$ HENDRIK GAMALIEL ${ }^{3)}$
}

\author{
Program Studi Magister Akuntansi Fakultas Ekonomi dan bisnis Universitas Sam Ratulangi \\ E-mail: lesli aimbu@yahoo.com
}

\begin{abstract}
The phenomenon can be observed in the development of the public sector today is the rise of increasingly demands to implement public accountability by public sector organizations (such as: the Central Government and the regions, Government work units, departments and State agencies). Public sector accountability demands are related to the necessity of conducting transparency and providing information to public, in order to fulfill the rights of the public. This research aims to analyze the variables of transformational leadership style, the competence of human resources (HR), organizational commitment, the use of management information systems area (SIMDA) finance and financial reporting against accessibility accountability financial management areas. The population in this research is financial management officers in Talaud Islands Regency SKPD. 175 respondents were taken to answer questionnaires in order to test the hypothesis and to know the influence of transformational leadership style, the competence of human resources (HR), organizational commitment, the use of Financial SIMDA and the accessibility of financial reports towards the accountability of financial management. $F$ test and t-test analysis were conducted by using multiple linear regression. Results show that transformational leadership style, the competence of human resources (HR), organizational commitment, the use and accessibility of Finance SIMDA financial report simultaneously, positively and significantly influence the regional financial management accountability. On the other hand, transformational leadership style, the competence of human resources (HR), the use of financial SIMDA and the accessibility of financial report positively and significantly influence the accountability of financial management. Nevertheless, organisatonal commitment does not positively influence the accountability of financial management.
\end{abstract}

Keywords: transformational leadership style, the competence of human resources (HR), organizational commitment, the use of Financial SIMDA and the accessibility of financial reports, the accountability of financial management

Abstrak. Fenomena yang dapat diamati dalam perkembangan sektor publik dewasa ini adalah semakin menguatnya tuntutan pelaksanaan akuntabilitas publik oleh organisasi sektor publik (seperti: pemerintah pusat dan daerah, unit-unit kerja pemerintah, departemen dan lembaga negara). Tuntutan akuntabilitas sektor publik terkait dengan perlunya dilakukan transparansi dan pemberian informasi kepada publik dalam rangka pemenuhan hak-hak publik. Penelitian ini bertujuan untuk menganalisis variabel gaya kepemimpinan transformasional, kompetensi Sumber Daya Manusia (SDM), komitmen organisasi, penggunaan Sistem Informasi Manajemen Daerah (SIMDA) Keuangan dan aksesibilitas laporan keuangan terhadap akuntabilitas pengelolaan keuangan daerah. Populasi pada penelitian ini adalah pejabat yang terkait dengan proses pengelolaan keuangan daerah di SKPD Kabupaten Kepulauan Talaud yaitu sebanyak 175 orang dan metode sensus dilakukan untuk mengambil sampel, sehingga banyaknya sampel sama dengan jumlah populasi yaitu sebanyak 175 orang untuk menguji hipotesis gaya kepemimpinan transformasional, kompetensi Sumber Daya Manusia (SDM), komitmen organisasi, penggunaan SIMDA Keuangan dan aksesibilitas laporan keuangan terhadap akuntabilitas pengelolaan keuangan daerah secara bersama-sama dengan Uji $\mathrm{F}$ dan sendiri-sendiri digunakan dengan Uji t menggunakan metode analisis linier berganda dengan aplikasi SPSS. Hasil penelitian membuktikan bahwa secara bersama-sama gaya kepemimpinan transformasional, kompetensi Sumber Daya Manusia (SDM), komitmen organisasi, penggunaan SIMDA Keuangan dan aksesibilitas laporan keuangan berpengaruh positif dan signifikan terhadap akuntabilitas pengelolaan keuangan daerah. Secara parsial gaya kepemimpinan transformasional, kompetensi Sumber Daya Manusia (SDM), penggunaan SIMDA Keuangan dan aksesibilitas laporan keuangan berpengaruh positif dan signifikan terhadap akuntabilitas pengelolaan keuangan daerah. Sedangkan komitmen organisasi tidak berpengaruh positif terhadap akuntabilitas pengelolaan keuangan daerah.

Kata Kunci : Gaya kepemimpinan transformasional, kompetensi Sumber Daya Manusia, komitmen organisasi, penggunaan SIMDA Keuangan dan aksesibilitas laporan keuangan, akuntabilitas pengelolaan keuangan daerah. 


\section{Pendahuluan}

Kebijakan yang dibuat melalui perangkat aturan tentang keuangan daerah/negara, dapat dilihat bahwa adanya tuntutan pelaksanaan fungsi pemerintah secara khusus pengelolaan keuangan publik menjadi lebih transparan dan akuntabel. Hal ini merupakan salah satu pelajaran penting dari pengalaman pengelolaan di era orde baru. Senada dengan tuntutan pengelolaan keuangan yang akuntabel, Mardiasmo (2009) mengemukakan bahwa fenomena yang dapat diamati dalam perkembangan sektor publik dewasa ini adalah semakin menguatnya tuntutan pelaksanaan akuntabilitas publik oleh organisasi sektor publik (seperti: pemerintah pusat dan daerah, unit-unit kerja pemerintah, departemen dan lembaga negara). Jika dirumuskan secara sederhana, keuangan yang akuntabel adalah keuangan yang direncanakan sesuai dengan kebutuhan dan dari segi proses harus melibatkan masyarakat (partisipatif) serta diimplementasikan secara transparan, jauh dari kepentingan politik tertentu dan dilaksanakan untuk mencapai tujuan otonomi daerah. Dengan adanya akuntabilitas pemerintah daerah, masyarakat dapat berperan dalam memantau kinerja pemerintah daerah, sehingga jalannya pemerintahan dapat berlangsung dengan baik.

Dalam menciptakan dan meningkatkan akuntabilitas pengelolaan keuangan daerah ada beberapa faktor yang menentukan diantaranya (1) Gaya kepemimpinan Transformasional. Plumpere (1981) pada artikelnya yang berjudul "perspective accountability in the public sector" menyatakan bahwa keberhasilan untuk mencapai akuntabilitas salah satu unsurnya yaitu kepemimpinan yang patut dicontoh (Exemplary leadership) (LAN dan BPKP, 2002). Kepemimpinan patut dicontoh tersebut merujuk pada bentuk kepemimpinan transformasional. Penelitian Wiratno, Pratiwi dan Nurkhikmah (2016) menyatakan gaya kepemimpinan berpengaruh signifikan terhadap akuntabilitas; (2) Kompetensi Sumber Daya Manusia, akuntabilitas dapat diwujudkan dengan kualitas Sumber Daya Manusia (SDM) yang handal (LAN dan BPKP, 2000). SDM merupakan aset utama organisasi yang mempunyai peran strategis untuk pencapaian tujuan organisasi yang didalamnya adalah tercapainya akuntabilitas pengelolaan keuangan. Penelitian Sihaloho (2014) membuktikan bahwa kualitas SDM berpengaruh signifikan terhadap akuntabilitas keuangan; (3) Komitmen Organisasi, dalam pelaksanaan akuntabilitas di lingkungan instansi pemerintah, perlu memperhatikan prinsip akuntabilitas yang salah satunya yaitu komitmen dari seluruh pimpinan dan seluruh staf instansi untuk melakukan pengelolaan pelaksanaan misi agar akuntabel (LAN dan BPKP, 2000). Penelitian Penelitian Wiratno, Pratiwi dan Nurkhikmah (2016) membuktikan komitmen organisasi berpengaruh signifikan terhadap akuntabilitas. (4) Penggunaan Sistem Informasi Manajemen Daerah (SIMDA) Keuangan, aplikasi SIMDA Keuangan merupakan produk dari Badan Pengawasan Keuangan dan Pembangunan Republik Indonesia. Aplikasi ini digunakan dalam pengelolaan keuangan hingga penyajian laporan keuangan. Selain itu aplikasi ini dipergunakan sebagai alat bantu pemerintah daerah. Alat bantu untuk meningkatkan efektifitas implementasi dari berbagai regulasi bidang pengelolaan keuangan daerah yang berdasarkan pada asas efesiensi, ekonomis, efektif, transparan, akuntabel dan auditable (BPKP,2014). Penelitian Sihaloho (2014 menunjukan penerapan teknologi informasi berpengaruh signifikan terhadap akuntabilitas keuangan. (5) Aksesibilitas Laporan Keuangan. Tuntutan akuntabilitas sektor publik terkait dengan perlunya dilakukan transparansi dan pemberian informasi kepada publik dalam rangka pemenuhan hak-hak publik (Mardiasmo, 2009). Nurrizkiana (2016) memberikan bukti dalam penelitian berjudul "Determinan Transparansi dan Akuntabilitas Pengelolaan Keuangan Daerah dan Implikasinya Terhadap Kepercayaan Public-Stakeholders" bahwa aksesibilitas laporan keuangan daerah berpengaruh signifikan terhadap akuntabilitas pengelolaan keuangan daerah. Ini menunjukkan bahwa laporan keuangan yang terbuka, tersedia dan mudah diperoleh oleh masyarakat akan meningkatkan akuntabilitas pengelolaan keuangan daerah. . 
Berdasarkan uraian di atas, maka menjadi motivasi untuk diadakan penelitan mengenai pengaruh gaya kepemimpinan transformasional, kompetensi SDM, komitmen organisasi, Penggunaan SIMDA Keuangan dan aksesibilitas laporan keuangan terhadap akuntabilitas pengelolaan keuangan daerah. kerangka berpikir penelitian ini sebagaimana pada gambar 1.

Gambar 1 Kerangka Pemikiran

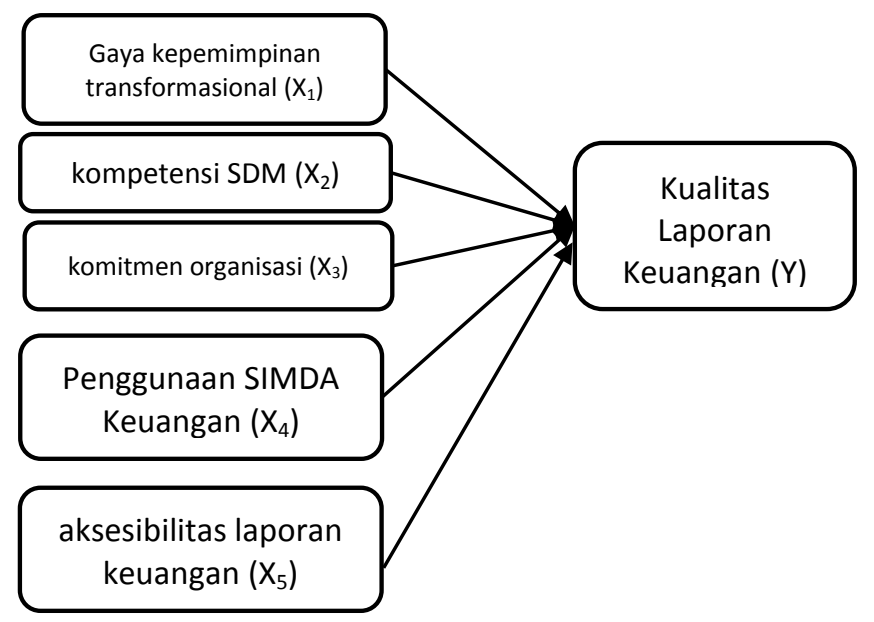

Teori kepemimpinan, yang dianggap efektif / unggul adalah teori transformasional; suatu pendekatan kepemimpinan dengan melakukan usaha mengubah kesadaran, membangkitkan semangat dan mengilhami bawahan atau anggota organisasi untuk mengeluarkan usaha ekstra dalam mencapai tujuan organisasi, tanpa merasa ditekan atau tertekan (Buntara, 2013). Kepemimpinan transformasional inilah yang sungguh-sungguh diartikan sebagai kepemimpinan yang sejati karena kepemimpinan ini sungguh bekerja menuju sasaran pada tindakan mengarahkan organisasi kepada suatu tujuan yang tidak pernah diraih sebelumnya (Yukl, 1998).

Keputusan Kepala Badan Kepegawaian Negara Nomor 46A Tahun 2003 Tanggal 21 November 2003 disebutkan bahwa kompetensi adalah, "kemampuan dan karakteristik yang dimiliki seorang Pegawai Negeri Sipil berupa pengetahuan, keterampilan, dan sikap perilaku yang diperlukan dalam pelaksanaan tugas jabatannya, sehingga Pegawai Negeri Sipil tersebut dapat melaksanakan tugasnya secara profesional, efektif, dan efisien". Akuntabilitas didadalamnya pengelolaan keuangan daerah dapat diwujudkan dengan kualitas sumber daya manusia yang handal (LAN dan BPKP, 2000). Salah satu asumsi yang sering dikemukakan adalah berhasil-tidaknya suatu organisasi mencapai visi dan misinya secara berkelanjutan sangat tergantung pada kualitas sumber daya manusia. Dengan demikian dukungan sumber daya manusia yang berkompetensi, yaitu mampu melaksanakan tugas dan tanggung jawab yang diberikan kepadanya dengan bekal pendidikan, pelatihan, dan pengalaman yang cukup memadai sangat diperlukan terselenggaranya akuntabilitas (Kharis, 2010).

Komitmen organisasi yang kuat dijelaskan sebagai kesesuaian dengan tujuan organisasi dan kemauan berusaha yang keras untuk kepentingan organisasi (Minan, 2005). Komitmen organisasi menunjukkan keyakinan dan dukungan yang kuat terhadap nilai dan sasaran (goal) yang ingin dicapai oleh organisasi (Mowday et al, 1979). Misi dan tujuan organisasi adalah terselenggaranya akuntabilitas dalam semua kegiatan. Komitmen dari seluruh pimpinan dan seluruh staf instansi untuk melakukan pengelolaan pelaksanaan misi agar akuntabel sangat penting (LAN dan BPKP, 2000).

Sistem Informasi Manajemen Daerah (SIMDA) Keuangan berfungsi membantu dalam pengelolaan keuangan hingga penyajian laporan keuangan pemerintah daerah untuk meningkatkan efektifitas implementasi dari berbagai regulasi bidang pengelolaan keuangan 
daerah yang berdasarkan pada asas efesiensi, ekonomis, efektif, transparan, akuntabel dan auditable (BPKP, 2000). Dengan dimanfaatkannya SIMDA Keuangan dalam proses pengelolaan keuangan daerah maka akan menciptakan akuntabilitas dalam kegiatan-kegiatan tersebut.

Ketidakmampuan laporan keuangan dalam melaksanakan akuntabilitas, disebabkan juga karena laporan tersebut tidak dapat secara langsung tersedia dan aksesibel pada para pengguna potensial (Jones et al., 1985). Oleh karena itu, pemerintah daerah harus meningkatkan aksesibilitas laporan keuangannya, tidak sekedar menyampaikannya ke DPRD saja, tetapi juga memfasilitasi masyarakat luas agar dapat mengetahui atau memperoleh laporan keuangan dengan mudah. Akuntabilitas yang efektif tergantung kepada akses publik terhadap laporan pertanggungjawaban maupun laporan temuan yang dapat dibaca dan dipahami. Dalam demokrasi yang terbuka, akses ini diberikan oleh media, seperti surat kabar, majalah, radio, stasiun televisi, dan website (internet); dan forum yang memberikan perhatian langsung atau peranan yang mendorong akuntabilitas pemerintah terhadap masyarakat (Shende dan Bennet, 2004).

\section{Metode Penelitian}

Penelitian ini merupakan jenis penelitian kuantitatif yang bertujuan memberikan bukti empiris pengaruh gaya kepemimpinan transformasional (X1), kompetensi SDM (X2), Komitmen Organisasi (X3), Penggunaan SIMDA Keuangan (X4) dan aksesibilitas laporan keuangan terhadap akuntabilitas pengelolaan keuangan daerah. Teknik analisis yang digunakan adalah analisis regresi linear berganda.

Penelitian ini dilakukan pada Pemerintah Kabupaten Kepulauan Talaud. Populasi dalam penelitian ini yaitu Pejabat-pejabat di bagian keuangan dan akuntansi SKPD, terdiri dari Sekretaris SKPD (Pejabat Penatausahaan Keuangan SKPD), Kepala Sub Bagian Keuangan, Kepala Sub Bagian Perencanaan, Evaluasi Dan Pelaporan, Bendahara pengeluaran, Bendahara penerimaan, dan Verifikator Keuangan.

Dalam penelitian ini, peneliti menganggap jumlah populasi relatif sedikit maka digunakan metode sensus. Dengan demikian dalam penelitian ini jumlah populasi sama dengan jumlah sampel yaitu sebanyak 175 orang yang tersebar di 33 SKPD Pemerintah Kabupaten Kepulauan Talaud

Gaya kepemimpinan transformasional diukur dengan indikator kondisi barang yang ada, kebutuhan barang yang akan datang dan penganggaran dengan menggunakan 11 (sebelas) pernyataan. Penilaian diukur dengan indikator tujuan penilaian, standar penilaian dan objek penilaian dengan menggunakan 9 (sembilan) pernyataan. Penatausahaan diukur dengan indikator pembukuan, inventarisasi dan pelaporan, dengan menggunakan 11 (sebelas) pernyataan. Pengawasan dan pengendalian diukur indikator dengan supervisi, pemantauan, pembagian tugas dan wewenang, audit APIP dengan menggunakan 19 (Sembilan belas) pernyataan. Kualitas laporan keuangan diukur dengan indikator relevan, andal, dapat dibandingkan, dan dapat dipahami dengan menggunakan 14 (empat belas) pernyataan. Masingmasing item pernyataan tersebut kemudian diukur dengan menggunakan Skala Likert 5 point.

\section{Hasil dan Pembahasan}

Data dalam penelitian ini yaitu data primer yang dikumpulkan dengan cara menyebarkan kuesioner langsung kepada 158 responden yang tersebar pada 33 SKPD di Kabupaten Kepulauan Talaud. Sebanyak 158 kuesioner yang disebarkan, terkumpul sebanyak 142 kuesioner, hal ini disebabkan karena pada saat dikumpul, beberapa kuesioner tidak dikembalikan oleh responden. Dari 142 kuesioner yang dikembalikan, terdapat 3 kuesioner yang tidak dapat digunakan karena tidak diisi dengan lengkap, sehingga kuesioner yang dapat diolah sebanyak 139 kuesioner. 
Untuk mendapatkan kualitas data dari suatu instrument telah dilakukan uji validitas dan reliabilitas. Pengujian validitas dalam penelitian ini menggunakan Pearson Correlation yaitu dengan cara menghitung korelasi antara skor masing-masing butir pernyataan dengan skor total. Jika korelasi antara skor masing-masing butir pernyataan dengan skor total mempunyai tingkat signifikansi $<0,05$, maka butir pernyataan tersebut dinyatakan valid dan sebaliknya. Hasil uji coba menunjukkan bahwa semua item pernyataan untuk variabel perencanaan, penilaian, penatausahan, pengawasan dan pengendalian BMD memiliki kriteria valid dengan nilai signifikansi $<0,05$. Hal ini berarti semua item pernyataan yang digunakan dalam penelitian ini mampu mengungkapkan semua variabel yang diukur pada kuesioner tersebut.

Pengujian reliabilitas dilakukan menggunakan teknik Cronbach Alpha. Suatu instrumen dapat dikatakan reliabel bila memiliki koefisien keandalan atau Cronbach Alpha $\geq 0,60$. Berdasarkan uji reliabilitas menunjukkan nilai Cronbach's Alpha untuk variabel perencanaan BMD sebesar 0,808; penilaian BMD sebesar 0,842; penatausahaan BMD sebesar 0,799; pengawasan dan pengendalian BMD sebesar 0,916 dan kualitas laporan keuangan pemerintah daerah 0,922. Dengan demikian dapat disimpulkan bahwa pernyataan dalam kuesioner ini reliable karena memiliki nilai Cronbach's Alpha $>0,60$. Hal ini menunjukkan bahwa apabila pernyataan diajukan kembali akan diperoleh jawaban yang relatif sama dengan jawaban sebelumnya.

Uji normalitas dilakukan untuk mengetahui data berdistribusi normal. Uji normalitas dalam penelitian ini dengan menggunakan grafik P-Plot SPSS dan uji normalitas KolmogorovSmirnov. Melalui grafik P-Plot dapat dinilai dari titik-titik penyebaran disekitar garis diagonal apakah searah dan mengikuti garis diagonal, sedangkan pada uji normalitas KolmogorovSmirnov akan dilihat nilai signifikansinya apabila lebih dari 0,05 maka data tersebut berdistribusi normal. Berdasarkan uji normalitas dengan grafik P-Plot SPSS, didapatkan bahwa titik data menyebar di sekitar garis diagonal dan penyebaran titik-titik data searah mengikuti garis diagonal. Berdasarkan uji normalitas Kolmogorov-Smirnov dilihat bahwa nilai asymp.sig (2-tailed) atau signifikansi sebesar 0,189 lebih besar dari 0.05 sehingga dapat disimpulkan bahwa data yang diuji berdistribusi normal. Dengan demikian model regresi telah memenuhi asumsi normalitas.

Pengujian multikolinieritas dilakukan untuk melihat apakah pada model regresi ditemukan adanya korelasi antara variabel independen. Cara mendeteksinya adalah dengan melihat nilai tolerance dan nilai Variance Inflation Factor (VIF). Jika nilai VIF < 10 dan tolerance > 0,1 maka variabel independen terbebas dari persoalan multikolinieritas. Hasil uji SPSS menunjukkan bahwa semua nilai tolerance $>0,1$ dan nilai $\mathrm{VIF}<10$. Hasil uji SPSS menunjukkan bahwa semua nilai tolerance $>0,1$ dan nilai $\mathrm{VIF}<10$. Hal ini menunjukkan bahwa semua variabel independen terbebas dari multikolinieritas.

Uji heterokedastisitas dilakukan untuk mengetahui apkah dalam sebuah model regresi terjadi ketidaksamaan varians dari residual suatu pengamatan ke pengamatan lain. Ada tidaknya heteroskedastisitas dapat ditentukan dengan melihat grafik plot antara nilai prediksi variabel terikat dengan residual. Jika grafik plot menunjukkan suatu pola titik yang bergelombang atau melebar kemudian menyempit, maka dapat disimpulkan bahwa telah terjadi heteroskedastisitas. Namun jika tidak ada pola yang jelas, yaitu serat titik-titik menyebar di atas dan di bawah angka 0 pada sumbu $Y$, maka tidak terjadi heteroskedastisitas. Hasil uji menunjukkan bahwa pada scatterplot, titik-titik yang ada tidak membentuk sebuah pola namun menyebar, sehingga dapat disimpulkan bahwa dalam penelitian tidak terjadi heterokedastisitas. 
Tabel 1. Hasil Regresi Linear Berganda

\begin{tabular}{|c|c|c|c|c|c|c|c|c|}
\hline \multicolumn{7}{|c|}{ Coefficients $^{\mathrm{a}}$} & \multirow{2}{*}{\multicolumn{2}{|c|}{$\begin{array}{l}\text { Collinearity } \\
\text { Statistics }\end{array}$}} \\
\hline & \multirow{2}{*}{ Model } & \multicolumn{2}{|c|}{$\begin{array}{l}\text { Unstandardize } \\
\text { d Coefficients }\end{array}$} & \multirow{2}{*}{$\begin{array}{c}\begin{array}{c}\text { Standardi } \\
\text { zed }\end{array} \\
\begin{array}{c}\text { Coefficien } \\
\text { ts }\end{array} \\
\text { Beta }\end{array}$} & \multirow{2}{*}{$\mathrm{t}$} & \multirow{2}{*}{ Sig. } & & \\
\hline & & B & $\begin{array}{l}\text { Std. } \\
\text { Error }\end{array}$ & & & & $\begin{array}{c}\text { Toleranc } \\
\mathrm{e}\end{array}$ & VIP \\
\hline \multirow{5}{*}{1} & (Constant) & $\begin{array}{r}13.53 \\
0\end{array}$ & 5.880 & & 2.301 & .023 & & \\
\hline & perencanaan & -.064 & .116 & -.045 & -.557 & .578 & .718 & $\begin{array}{r}1.39 \\
4\end{array}$ \\
\hline & penilaian & .310 & .133 & .222 & 2.336 & .021 & .511 & $\begin{array}{r}1.95 \\
6\end{array}$ \\
\hline & $\begin{array}{l}\text { penatausaha } \\
\text { an }\end{array}$ & .425 & .130 & .281 & 3.261 & .001 & .619 & $\begin{array}{r}1.61 \\
5\end{array}$ \\
\hline & $\begin{array}{l}\text { Pengawasan } \\
\text { dan } \\
\text { pengedalian }\end{array}$ & .243 & .065 & .310 & 3.744 & .000 & .673 & $\begin{array}{r}1.48 \\
6\end{array}$ \\
\hline
\end{tabular}

Hasil pengujian asumsi klasik menunjukkan bahwa model regresi yang dipakai telah memenuhi asumsi klasik sehingga dapat dilanjutkan dengan analisis regresi berganda. Model regresi berganda dalam penelitian ini adalah untuk menguji pengaruh perencanaan $B M D\left(X_{1}\right)$, penilaian BMD $\left(\mathrm{X}_{2}\right)$, penatausahaan $\mathrm{BMD}\left(\mathrm{X}_{3}\right)$ dan pengawasan dan pengendalian $\mathrm{BMD}\left(\mathrm{X}_{4}\right)$, terhadap kualitas laporan keuangan pemerintah daerah $(\mathrm{Y})$.

Pengujian hipotesis dengan uji $\mathrm{F}$ (Fisher Test) dilakukan untuk menunjukkan apakah semua variabel independen yang digunakan dalam model regresi mempunyai pengaruh yang signifikan secara bersama-sama (simultan) terhadap variabel dependen. Berdasarkan tabel distribusi $F$, nilai $F_{\text {tabel }}=2,43$. Hasil uji $F$ didapatkan $F_{\text {hitung }}=20.834$, hal ini menunjukkan bahwa $F_{\text {hitung }}=20.834>F_{\text {tabel }}=2,43$ maka Ha diterima dan Ho ditolak. Dilihat dari nilai signifikansi menunjukkan bahwa nilai signifikansi adalah 0,000 $<0,005$ sehingga Ha diterima dan Ho ditolak. Hasil pengujian ini menunjukkan bahwa seluruh variabel independen yaitu perencanaan $\mathrm{BMD}$, penilaian $\mathrm{BMD}$, penatausahaan $\mathrm{BMD}$, pengawasan dan pengendalian BMD secara bersama-sama berpengaruh secara signifikan terhadap variabel dependen yaitu kualitas laporan keuangan pemerintah daerah.

Pengujian hipotesis dengan uji t dilakukan untuk mengetahui besarnya pengaruh masingmasing (parsial) variabel independen secara individual terhadap variabel dependen. Uji t juga dilakukan dengan membandingkan nilai $t_{\text {hitung }}$ dengan nilai $t_{\text {tabel }}$. Nilai $t_{\text {hitung }}$ diperoleh dari hasil perhitungan SPSS sedangkan $t_{\text {tabel }}$ diperoleh dari tabel distribusi t dicari pada $\alpha=5 \%: 2=2,5 \%$ (uji 2 sisi) dengan derajat kebebasan (df) n-k-1 atau 139-4-1 = 134. Dengan pengujian 2 sisi (signifikansi $=0,025$ ) hasil diperoleh untuk $t_{\text {tabel }}$ sebesar 1,960 .

Pengaruh perencanaan BMD terhadap kualitas laporan keuangan pemerintah daerah, nilai $=-0.557<t_{\text {tabel }}=1,960$ dan signifikansi sebesar 0,578 $>0,05$. Hal ini menunjukkan bahwa $\mathrm{Ha}_{1}$ ditolak dan $\mathrm{Ho}_{1}$ diterima, sehingga terbukti bahwa perencanaan BMD tidak berpengaruh signifikan terhadap kualitas laporan keuangan pemerintah daerah.

Pengaruh penilaian BMD terhadap kualitas laporan keuangan pemerintah daerah, $t_{\text {hitung }}=$ $2.336>t_{\text {tabel }}=1,960$ dan Signifikansi sebesar 0,021 $<0,05$. Hal ini menunjukkan bahwa $\mathrm{Ha}_{2}$ 
diterima dan $\mathrm{Ho}_{2}$ ditolak, sehingga terbukti bahwa penilaian BMD berpengaruh signifikan terhadap kualitas laporan keuangan pemerintah daerah.

Pengaruh penatausahaan BMD terhadap kualitas laporan keuangan pemerintah daerah, nilai $t_{\text {hitung }}=3,261>t_{\text {tabel }}=1,960$ dan signifikansi sebesar $0,001<0,05$. Hal ini menunjukkan bahwa $\mathrm{Ha}_{3}$ diterima dan $\mathrm{Ho}_{3}$ ditolak, sehingga terbukti bahwa penatausahaan BMD berpengaruh signifikan terhadap kualitas laporan keuangan pemerintah daerah.

Pengaruh pengawasan dan pengendalian BMD terhadap kualitas laporan keuangan pemerintah daerah, $t_{\text {hitung }}=3.744>t_{\text {tabel }}=1,960$ dan signifikan sebesar $0,000<0,05$. Hal ini menunjukkan bahwa $\mathrm{Ha}_{4}$ diterima dan $\mathrm{Ho}_{4}$ ditolak, sehingga terbukti bahwa pengawasan dan pengendalian BMD berpengaruh signifikan terhadap kualitas laporan keuangan pemerintah daerah.

Uji koefisien determinasi dalam regresi linear berganda, untuk regresi dengan lebih dari dua variabel bebas digunakan adjusted $R^{2}$ sebagai koefisien determinasi. Berdasarkan hasil uji, nilai adjusted $\mathrm{R}^{2}$ adalah 0,365 yang artinya kualitas laporan keuangan pemerintah daerah sebesar $36,5 \%$ dipengaruhi oleh perencanaan $B M D$, penilaian BMD, penatausahaan BMD dan pengawasan dan pengendalian BMD sedangkan sisanya 63,5\% dipengaruhi oleh faktor lain di luar penelitian ini.

\section{Pengaruh perencanaan BMD terhadap kualitas LKPD}

Hasil pengujian hipotesis pertama menunjukkan bahwa nilai koefisien regresi perencanaan BMD adalah 0,064 dengan arah negatif dan $t_{\text {hitung }}=-0,557<t_{\text {tabel }}=1,960$ serta nilai Signifikansi sebesar 0,578 0,05 menunjukkan bahwa perencanaan BMD berpengaruh negatif dan tidak signifikan secara statistik terhadap kualitas laporan keuangan Pemerintah Daerah Kabupaten Kepulauan Talaud.

Penelitian ini berpendapat bahwa diperolehnya temuan yang berlawanan dengan hipotesis dapat dijelaskan melalui beberapa permasalahan yang terkait dengan proses perencanaan BMD di Kabupaten Kepulauan Talaud sehingga berdampak pada penurunan kualitas laporan keuangan pemerintah daerah. Pertama, proses perencanaan kebutuhan dan pemeliharaan barang SKPD terlihat tiap tahunnya, selalu mengajukan barang yang hampir sama dengan kebutuhan tahun sebelumnya, tanpa terlebih dahulu dilakukan analisis kebutuhan dan skala prioritas pemeliharaan barang. Sehingga ada kekuatiran dari Tim Anggaran dalam mengambil keputusan kebutuhan dan pemeliharaan barang daerah karena kurang percaya terhadap kebenaran pengajuan tersebut. Kedua, masih ada SKPD yang melaksanakan perencanaan barang belum sesuai dengan standar harga. Hal ini akan menurunkan kualitas laporan keuangan karena dianggap belum memenuhi aspek relevan dan andal, karena belum menyajikan informasi aset/barang yang dapat dipakai untuk memprediksi kebutuhan barang dimasa akan datang juga tidak bisa dipakai dalam pengambilan keputusan pengelolaaan BMD.

Menurut Yusuf (2015:9), pengelolaan aset/BMD merupakan komponen yang sangat penting untuk mewujudkan laporan keuangan yang lebih baik/berkualitas. Perencenaan BMD yang merupakan tahapan awal dan penting dalam proses pengelolaan aset/BMD harus dilakukan secara optimal dan efisien.

Hasil penelitian ini tidak mendukung penelitian yang dilakukan Hidayat et al (2016). Hasil penelitiannya menunjukkan bahwa perencanaan BMD berpengaruh signifikan terhadap kualitas laporan keuangan. Demikian juga penelitian Evira (2015), Hasil penelitiannya menunjukkan bahwa perencanaan berpengaruh secara signifikan terhadap kewajaran penyajian aset di laporan keuangan pemerintah daerah. 


\section{Pengaruh penilaian BMD terhadap kualitas LKPD}

Hasil pengujian hipotesis kedua menunjukkan bahwa variabel penilaian barang milik daerah, $t_{\text {hitung }}=2,336>t_{\text {tabel }}=1,960$ serta nilai Signifikansi sebesar $0,021<0,05$ sehingga penilaian BMD berpengaruh signifikan terhadap kualitas laporan keuangan pemerintah daerah. Nilai koefisien regresi penilaian BMD sebesar 0,310 dan bernilai positif menunjukkan jika penilaian barang milik daerah semakin baik akan meningkatkan kualitas laporan keuangan pemerintah daerah Kabupaten Kepulauan Talaud.

Menurut Kementerian Keuangan (2013), kegiatan penilaian dilakukan dalam rangka pengelolaan BMD yang merupakan implementasi tindakan untuk mendukung kepastian nilai, yaitu adanya ketepatan jumlah dan nilai barang dalam rangka optimalisasi pemanfaatan dan pemindatanganan BMD serta penyusunan neraca pemerintah daerah. Selanjutnya, Bastian (2006) menjelaskan bahwa neraca awal memiliki peran yang sangat penting karena akan terbawa terus dan dipakai sebagai dasar dalam menentukan posisi keuangan pemerintah serta akan memberikan informasi penting kepada manajemen pemerintah dan stakeholder tentang posisi atau keadaan dari kekayaan atau aset daerah beserta liabilitas dan ekuitas dananya pada tanggal tertentu. Sehingga penilaian barang yang merupakan tahapan pengelolaan BMD, sangat penting untuk mewujudkan laporan keuangan yang lebih baik (Yusuf 2015:9). Karena hasil penilaian inilah yang akan dijadikan dasar untuk melakukan perbaikan pengelolaan aset/barang daerah sehingga dapat dimanfaatkan secara maksimal.

Hal ini mengkonfirmasi asumsi filosofis dari teori kepatuhan yang menjelaskan bahwa seorang individu cenderung mematuhi hukum yang mereka anggap sesuai dan konsisten dengan norma-norma internal mereka. Dalam proses pengelolaaan BMD khususnya penilaian BMD harus memenuhi kepatuhan terhadap peraturan perundang-undangan yang berlaku.

Hasil penelitian ini mendukung penelitian yang dilakukan Anshari (2016) dan Simamora (2012) yang membuktikan bahwa penilaian aset/barang mempengaruhi kualitas laporan keuangan, juga penelitian Ristiasiri (2014) yang membuktikan bahwa penilaian aset tetap berpengaruh terhadap persepsi penyajian nilai wajar neraca Pemerintah Kota Banjarbaru.

Hasil penelitian ini tidak mendukung penelitian Hidayati, et al. (2016), hasil penelitiaannya menunjukkan bahwa pelaksanaan BMD yang salah satu faktornya penilaian BMD tidak terbukti berpengaruh signifikan terhadap kualitas laporan keuangan. Juga tidak mendukung penelitian Wiraputri (2012) pada Pemerintah Kabupaten/Kota Ciayu Majakuning, Subang, Karawang dan Purwakarta yang membuktikan bahwa pengelolaan BMD berpengaruh positif namun tidak signifikan terhadap kualitas laporan keuangan.

\section{Pengaruh Penatausahaan BMD terhadap Kualitas LKPD}

Hasil pengujian hipotesis ketiga menunjukkan bahwa pada variabel penatausahaan BMD, $t_{\text {hitung }}=3,261>t_{\text {tabel }}=1,960$ dan nilai Signifikansi sebesar 0,001<0,05 sehingga penatausahaan BMD berpengaruh signifikan terhadap kualitas laporan keuangan pemerintah daerah. Nilai koefisien regresi sebesar 0,425 dan bernilai positif menunjukkan jika pelaksanaan penatausahaan BMD semakin baik akan meningkatkan kualitas laporan keuangan Pemerintah Daerah Kabupaten Kepulauan Talaud.

Menurut Kementerian Keuangan (2013), Penatausahaan/pencatatan barang daerah pada SKPD sangat penting dikarenakan catatan tersebut dijadikan objek audit oleh BPK dalam meyakini penyajian laporan keuangan SKPD dan Pemerintah Daerah. Dengan penatausahaan secara tertib, maka akan dihasilkan angka-angka yang tepat dan akurat yang berdampak pada tersedianya database yang memadai dalam menyusun perencanaan kebutuhan dan penganggaran serta akan menghasilkan laporan aset dineraca dengan angka yang tepat dan akurat sehingga akan meningkatkan kualitas laporan keuangan yang lebih baik. Selanjutnya Yusuf (2015:27) menjelaskan bahwa neraca daerah yang merupakan bagian dari komponen 
laporan keuangan akan lengkap dan dapat dipercaya jika penatausahaan aset antara fisik aset, dokumen pemilikan, dan penatausahaan dalam buku inventaris mempunyai kesesuaian. Dengan adanya alur penatausahaan yang sistematis maka tingkat kepercayaan terhadap proses penatausahaan akan selalu dapat dipercaya siapapun yang membaca laporan keuangan tersebut. Selain itu, BPK RI selaku auditor akan lebih mudah menelusuri aset dengan kriteria yang telah ditetapkan dalam standar akuntansi sehingga BPK RI tidak akan ragu dalam menilai tingkat kewajaran keberadaan aset baik secara administrasi ataupun secara fisik. Hal ini mengkonfirmasi asumsi filosofis dari teori kepatuhan yang menjelaskan bahwa seorang individu cenderung mematuhi hukum yang mereka anggap sesuai dan konsisten dengan norma-norma internal mereka. Dalam proses pengelolaaan BMD khususnya dalam proses perencanaan, penilaian, penatausahaan, pengawasan dan pengendalian harus memenuhi kepatuhan terhadap peraturan perundang-undangan yang berlaku.

Hasil penelitian ini mendukung penelitian yang dilakukan Anggareini (2015) dan Febrianti (2016) yang meneliti tentang pengaruh penatausahaan aset tetap terhadap kualitas laporan keuangan pemerintah daerah. Hasil penelitian menunjukkan penatausahaan berpengaruh positif dan signifikan terhadap kualitas laporan keuangan pemerintah daerah.

Hasil penelitian ini tidak mendukung penelitian Hidayati, et al. (2016), hasil penelitiaannya menunjukkan bahwa pelaksanaan BMD yang salah satunya penatausahaan tidak terbukti berpengaruh signifikan terhadap kualitas laporan keuangan.

\section{Pengaruh Pengawasan dan Pengendalian BMD terhadap Kualitas LKPD.}

Hasil pengujian hipotesis keempat menunjukkan bahwa pada variabel pengawasan dan pengendalian $B M D, t_{\text {hitung }}=3,744>t_{\text {tabel }}=1,960$ dan nilai signifikansi sebesar $0,000<0,05$ sehingga pengawasan dan pengendalian barang milik daerah berpengaruh signifikan terhadap kualitas laporan keuangan pemerintah daerah. Nilai koefisien regresi pengawasan dan pengendalian barang milik daerah sebesar 0,243 menunjukkan jika pengawasan dan pengendalian barang milik daerah semakin baik akan meningkatkan kualitas laporan keuangan Pemerintah Daerah Kabupaten Kepulauan Talaud.

Menurut Kementerian Keuangan (2013), untuk menjamin kelancaran penyelenggaraan dan menjamin tertib administrasi pengelolaan BMD secara efisien dan efektif maka diperlukan fungsi pembinaan, pengawasan, dan pengendalian atas aset/BMD. Selanjutnya Mardiasmo (2004:78) menegaskan bahwa pengawasan yang ketat perlu dilakukan sejak tahap perencanaan hingga penghapusan aset. Hal itu sangat penting untuk memastikan bahwa seluruh mekanisme dan prosedur pengelolaan BMD telah dilakukan sesuai dengan peraturan perundang-undangan. Sehingga pengelolaan aset/barang daerah semakin baik maka akan mewujudkan laporan keuangan yang lebik baik dan berkualitas (Yusuf, 2015:9).

Hal ini mengkonfirmasi asumsi filosofis dari teori atribusi yang menjelaskan bahwa tindakan seorang pemimpin maupun orang yang diberikan wewenang dipengaruhi oleh atribut penyebab (Green dan Mitchell dikutip oleh Adelin, 2013). Tindakan kecurangan dapat dipengaruhi adanya sistem pengendalian internal dan monitoring oleh atasan, sehingga dengan adanya pengendalian internal maka tindakan tidak etis akan berkurang. Jika keefektifan pengendalian internal tinggi maka perilaku tidak etis akan menurun. Dalam proses pengelolaan BMD diperlukan pengawasan dan pengendalian terhadap pelaksanaan pengelolaan BMD untuk menjamin kelancaran penyelenggaraan dan menjamin tertib administrasi pengelolaan BMD secara efisien dan efektif, serta memastikan bahwa seluruh mekanisme dan prosedur pengelolaan BMD telah dilakukan sesuai dengan peraturan perundang-undangan.

Hasil penelitian ini mendukung penelitian yang dilakukan Hidayat et al. (2016) dan Anshari (2016) yang meneliti tentang pengaruh pengelolaan BMD terhadap kualitas laporan 
keuangan pemerintah daerah. Hasil penelitian menunjukkan pengawasan dan pengendalian berpengaruh positif dan signifikan terhadap kualitas laporan keuangan pemerintah daerah.

\section{Kesimpulan dan Saran}

Hasil Penelitian menunjukkan bahwa secara parsial Perencanaan BMD berpengaruh negatif dan tidak signifikan secara statistik terhadap kualitas laporan keuangan Pemerintah Daerah Kabupaten Kepulauan Talaud. Penilaian, penatausahan, pengawasan dan pengendalian BMD berpengaruh positif dan signifikan terhadap kualitas laporan keuangan Pemerintah Daerah Kabupaten Kepulauan Talaud. Sedangkan secara simultan perencanaan, penilaian, penatausahaan, pengawasan dan pengendalian BMD berpengaruh positif dan signifikan terhadap kualitas laporan keuangan Pemerintah Daerah Kabupaten Kepulauan Talaud.

Saran yang dapat diberikan dalam penelitian ini agar Pemerintah Kabupaten Kepulauan Talaud, 1) perlu melakukan peningkatan kemampuan sumber daya aparatur pengelolah BMD dengan melakukan pendidikan dan pelatihan, 2) melakukan analisis kebutuhan dan skala prioritas pemeliharaan BMD sebelum melakukan perencanaan BMD, 3) melakukan kegiatan sensus BMD secara komprehensif mulai dari unit kerja/SKPD untuk mendapatkan data barang/aset yang benar dan dapat dipertanggungjawabkan serta nilai aset yang akurat (up to date), 4) harus lebih meningkatkan kinerja pengawasan dan pengendalian terhadap pengelolaan BMD serta 5) perlu adanya regulasi khusus tentang sistem dan prosedur pengelolaan BMD.

\section{Daftar Pustaka}

Adelin, Vani \& Eka Fauzihardani. 2013. Pengaruh Pengendalian Internal, Ketaaatan pada Aturan Akuntansi dan Kecenderungan Kecurangan Terhadap Perilaku Tidak Etis. WRA, Vol. 1, No. 2.

Anshari, Efrizal Syofyan. 2016. Pengaruh Pengelolaan Barang Milik Daerah Terhadap Kualitas Laporan Keuangan Pemerintah Kota Padang. Jurnal riset manajemen bisnis dan public, Vol. 4 No. 1.

Anggareini, Ayang Putri Septiayu. 2015. Pengaruh penatausahaan Barang Milik Negara terhadap kualitas laporan keuangan pada Kantor kementrian agama kota probolinggo. Tesis. Universitas Islam Negeri Maulana Malik Ibrahim Malang.

Badan Pemeriksa Keuangan, 2016. Ikhtisar Hasil Pemeriksaan Semester I Tahun 2016.

Bastian, Indra. 2009. Akuntansi Sektor Publik Suatu Pengantar Edisi Ketiga. Jakarta: Erlangga

BPPK Kemenkeu Republik Indonesia. 2011. Pembinaan, Pengawasan, dan Pengendalian Barang Milik Negara. Jakarta.

Evira. 2015. Manajemen aset daerah terhadap Kewajaran laporan keuangan pemerintah daerah menurut pp no. 71 tahun 2010 dan psap no. 07 (studi kasus pada pemerintah kabupaten Grobogan). Tesis. Universitas Sebelas Maret Surakarta

Febrianti, Sukma. 2016. Pengaruh Penatausahaan Aset Tetap Terhadap Kualitas Laporan Keuangan Pemerintah Kabupaten Kubu Raya. Jurnal Ekonomi Manajemen Vol. 10 No. 1

Ferdianus, 2013. Analisis penatausahaan aset tetap untuk menghasilkan data yang dipercaya dalam laporan barang milik daerah (studi pada pemerintah provinsi maluku). Tesis. Universitas Gajah Mada.

Hidayati, et al. 2016. Pengaruh siklus pengelolaan barang milik daerah terhadap kualitas laporan keuangan (studi empiris pada pemerintah kabupaten solok selatan). Jurnal Akuntansi vol 8, No.1

Kementrian Keuangan RI, 2013. Modul Pelatihan Pengelolaan Barang Milik Daerah. Edisi Tahun 2013. 
Mahmudi, 2015. Analisis Laporan Keuangan Pemerintah Daerah Edisi ketiga, Yogyakarta: UPP STIM YPKN.

Mardiasmo. 2009. Akuntansi sektor publik. Edisi keempat. Yogyakarta : Andi.

PP RI Nomor 71 Tahun 2010 tentang Standar Akuntansi Pemerintah.

PP RI Nomor 27 Tahun 2014 tentang Pengelolaan Barang Milik Negara.

Permendagri Nomor 17 Tahun 2007 tentang Pedoman Teknis Pengelolaan Barang Milik Daerah

Ristiasiri, Ratih. 2014. Pengaruh Inventarisasi Dan Penilaian Aset Tetap/Barang Milik Daerah Terhadap Persepsi Penyajian Nilai Wajar Neraca Di Pemerintah Kota Banjarbaru. Tesis. Universitas Gajah Mada.

Simamora, Rudianto. 2012. Faktor-faktor yang mempengaruhi pengelolaan aset pasca pemekaran wilayah dan pengaruhnya terhadap kualitas laporan keuangan Pemerintah di Kab. Tapanuli Selatan. Tesis.

Wiraputri, Maya Maulida (2012). Pengaruh Pengelolaan Barang Milik Daerah Terhadap Akuntabilitas dengan Kualitas Laporan Keuangan sebagai Variabel Intervening (Studi Kasus pada Pemerintah Kabupaten/Kota Ciayumajakuning, Subang, Karawang dan Purwakarta). Bandung.

Wungow, J. Fiesgrald. 2016. Pengaruh tingkat pendidikan, masa kerja, pelatihan dan jabatan terhadap kualitas laporan keuangan pemerintah Kabupaten Minahasa Selatan. Tesis.

Yusuf, M. 2015. 8 Langkah Pengelolaan Aset Daerah Menuju Pengelolaan Keuangan Daerah Terbaik. Salemba Empat. Jakarta. 